\title{
Epithelial Cell
}

National Cancer Institute

\section{Source}

National Cancer Institute. Epithelial Cell. NCI Thesaurus. Code C12578.

Any of the cells of the epithelium, which covers the body and lines its cavities and glands. 